\title{
Study Regarding the Romanian Consumer Ethnocentrism
}

\author{
Daniel CHICIUDEAN*), Sabina FUNAR, Gabriela CHICIUDEAN, Iulia MUREȘAN
}

Faculty of Horticulture, Department of Economic Sciences. University of Agricultural Sciences and Veterinary Medicine Cluj-Napoca,3-5 Mănăştur St. Romania;

*) corresponding author, e-mail: chiciudean.daniel@yahoo.com

BulletinUASVM Horticulture 72(1) / 2015

Print ISSN 1843-5254, Electronic ISSN 1843-5394

doi:10.15835/buasvmcn-hort:11066

\begin{abstract}
The concept of ethnocentrism was developed by Shimp and Sharma who believed that it is able to explain the judgement, often irrational of those consumers who prefer the local products instead of imported ones. The aim of this study is to determine the degree of ethnocentrism of the Romanian consumers given the relationship existing between this aspect and the consumer buying behaviour. A study was conducted among the people from Cluj-Napoca in 2013, on a sample of 277 people. The objective was to measure the ethnocentrism degree of the Romanian consumer using the "consumer ethnocentric tendencies scale" (CETSCALE) first developed by Shimp and Sharma in 1987 for the American consumers and than tested in many other countries from Europe, Asia and Africa. The CETSCALE comprises 17 affirmations using a seven point scale which were adapted for the Romanian people. In order to determine the consumer ethnocentrism degree, mean was calculated. The notion of consumer ethnocentrism is explained using principal components analysis and factor analysis. Results indicate that the mean of consumer ethnocentrism is 4.40 indicating a medium tendency. The value is comparable with the one obtained by Chryssochoidis et al (2006) meaning 3.85. Factor analysis indicated three important factors which explained $63.22 \%$ of the total variance. Finally two clusters were obtained using the three factors. It can be concluded that testing the CETSCALE for the Romanian consumers is a useful action because it helps marketers to determine the consumer general tendency in the decision making process for local products.
\end{abstract}

Keywords: CETSCALE, decision-making process, factor analysis

\section{INTRODUCTION}

The concept of ethnocentrism first appeared in 1906 in the Sociology field and developed by Shimp and Sharma (1987). They believe that the ethnocentrism concept is able to explain the judgement, often irrational of those consumers who prefer the local products instead of imported ones. Orth\&Firbasova (2002) analyzed how CETSCALE in combination with some demographical and psycho-graphical variables could be a predictor in evaluation the local Czech yoghurt by the consumers. Results indicated that the ethnocentrism is indeed a strong predictor in choosing the local products. Hamin \& Elliot (2006) observed that the Indonesian population has strong ethnocentric tendencies, therefore is very receptive at messages like: „buy local products". Chryssochoidis et al. (2006) examined the relation between the consumer ethnocentrism and their manner of evaluating the Greek products comparing to the imported ones. Results indicated that the ethnocentrism is stronger among older people, with lower level of incomes and less educated. The ethnocentric consumers evaluated more favourable the Greek products comparing to the less ethnocentric consumers. Urbanovicius et al. (2010) analyses the ethnocentrism influence over the decision of buying local organic products from Lithuania, focusing on vegetables, meat, milk and pastries. Results indicated a variation 
of ethnocentrism influence in purchasing these products, concluding that it is strongly related to the type of products. Teo et al. (2011) studied the ethnocentrism influence over the perception of Malaysian consumers regarding local products, observing a strong impact of it. So, local brands are perceived more favourable from the ethnocentric perspective.

\section{AIMS AND OBJECTIVES}

The aim of this study is to determine the degree of ethnocentrism of the Romanian consumers given the relationship existing between this aspect and the consumer buying behaviour.

\section{MATERIALS AND METHODS}

A study was conducted among the people from Cluj-Napoca in 2013, on a sample of 277 people. The objective was to measure the ethnocentrism degree of the Romanian consumer using the "consumer ethnocentric tendencies scale" (CETSCALE) first developed by Shimp and Sharma in 1987 for the American consumers and than tested in many other countries from Europe, Asia and Africa. The CETSCALE comprises 17 affirmations using a seven point Likert scale which were adapted for the Romanian people. In order to determine the consumer ethnocentrism degree, mean was calculated. The notion of consumer ethnocentrism is explained using principal components analysis and factor analysis.

\section{RESULTS}

Results indicate that the mean of consumer ethnocentrism is 4.40 indicating a medium tendency. The value is comparable with the one obtained by Chryssochoidis et al. (2006) meaning 3.85. Factor analysis indicated three important factors which explained $63.22 \%$ of the total variance unlike Crhyssochoidis et al. (2006) which obtained only two. The first factor- „strong ethnocentrism” - contains affirmations based on the idea of patriotism and encouraging local purchase considered a necessary element for a being a "true Romanian” the second factor highlights an attitude oriented against importation and foreign products while the third factor is a moderate ethnocentrism. Using the K-means Cluster Analysis two clusters were obtained based on the three factors. $60.29 \%$ of the respondents are non-ethnocentric consumers while 39.71\% are ethnocentric consumers. The first group is characterized by a moderate ethnocentrism while the second group by an attitude against imported products and a strong ethnocentrism.

Conclusion: It can be concluded that testing the CETSCALE for the Romanian consumers is a useful action because it helps marketers to determine the consumer general tendency in the decision making process for local products.

\section{REFERENCES}

1. Chryssochoidis G, Krystallis A, Perreas P (2007). Ethnocentric beliefs and country of origin effect. European journal of marketing. 41(11/12):1518-1544.

2. Hamin H, and Elliott G (2005). A Less-Developed Country Perspective Of "Country Of Origin" Effects:Indonesian Evidence, ANZMAC 2005 Conference: Marketing Issues in Asia, 32-38.

3. Orth UR ,Firbasova Z (2002). Ethnocentrism and consumer evaluations of Czech made yoghurt, Agricultural Economics, 48(4):175-181.

4. Shimp TA, Sharma S (1987). Consumer ethnocentrism:construction and validation of the CETSCALE. Journal of marketing research. 24: 280-289.

5. Teo PC, Mohamad 0, Ramayah T (201). Testing the dimmensionality of Consumer Ethnocentrism scale (CETSCALE) among a young Malaysian cosnumer market segment, African Journal of Business Management, 5(7):2805-2816.

6. Urbonavicius S, Dikcius V, Petrauskas A (2010). Impact of ethnocentrism on buyer's behaviour of organic food products, 6th International Scientific Conference Business and Management, ISSN 2029-4442, Vilnius, Lituania, 551516. 